\title{
Erythropoietin regulates POMC expression via STAT3 and potentiates leptin response
}

\author{
Soumyadeep Dey ${ }^{*}$ Xiaoxia $\mathrm{Li}^{*}{ }^{,}$, Ruifeng Teng, Mawadda Alnaeeli, ZhiYong Chen, \\ Heather Rogers and Constance Tom Noguchi
}

Molecular Medicine Branch, National Institute of Diabetes and Digestive and Kidney Diseases, National Institutes of Health, Building 10, Room 9N319, 10 Center Drive MSC-1822, Bethesda, Maryland 20892-1822, USA *(S Dey and X Li contributed equally to this work)

${ }^{\dagger} \mathrm{X} \mathrm{Li}$ is now at Department of Physiology and Pathophysiology, Peking University Health Science Center, Beijing 100191, China
Correspondence should be addressed to C T Noguchi Email connien@helix.nih.gov

\begin{abstract}
The arcuate nucleus of the hypothalamus is essential for metabolic homeostasis and responds to leptin by producing several neuropeptides including proopiomelanocortin (POMC). We previously reported that high-dose erythropoietin (Epo) treatment in mice while increasing hematocrit reduced body weight, fat mass, and food intake and increased energy expenditure. Moreover, we showed that mice with Epo receptor (EpoR) restricted to erythroid cells $\left(\Delta E E_{0} R_{E}\right)$ became obese and exhibited decreased energy expenditure. Epo/EpoR signaling was found to promote hypothalamus POMC expression independently from leptin. Herein we used WT and $\Delta E \mathrm{Epo}_{\mathrm{E}}$ mice and hypothalamus-derived neural culture system to study the signaling pathways activated by Epo in POMC neurons. We show that Epo stimulation activated STAT3 signaling and upregulated POMC expression in WT neural cultures. $\triangle E_{\text {ppoR }}$ mice hypothalamus showed reduced POMC levels and lower STAT3 phosphorylation, with and without leptin treatment, compared to in vivo and ex vivo WT controls. Collectively, these data show that Epo regulates hypothalamus POMC expression via STAT3 activation, and provide a previously unrecognized link between Epo and leptin response.
\end{abstract}

Journal of Molecular Endocrinology (2016) 56, 55-67

\section{Introduction}

The hematopoietic cytokine erythropoietin (Epo), the primary regulator of erythrocyte production, is mainly produced in the kidneys in a hypoxia-dependent manner. Epo receptor (EpoR) expression is highest in erythroid progenitors, and its deletion in mice $\left(\mathrm{EpoR}^{-1-}\right)$ is embryonic lethal due to severe anemia (Wu et al. 1995). In addition, EpoR signaling in non-hematopoietic cells has pleiotropic effects beyond erythropoiesis (Noguchi

\section{Key Words \\ - erythropoietin \\ - POMC \\ - hypothalamus and neuroendocrinology \\ - gene expression}


fat mass (Hojman et al. 2009, Katz et al. 2010, Foskett et al. 2011, Teng et al. 2011). Expression of an erythroid tissuespecific EPoR transgene rescued the embryonic lethal phenotype in EpoR ${ }^{-/-}$mice (Suzuki et al. 2002). This mouse model has EpoR expression restricted to erythroid tissue $\left(\Delta \mathrm{EpoR}_{\mathrm{E}}\right)$ (Suzuki et al. 2002). Previously, we reported that $\Delta \mathrm{EpoR}_{\mathrm{E}}$ mice exhibit increased body weight from the first postnatal week, show decreased energy expenditure, and develop metabolic syndromes with age via effects on white adipose tissue and hypothalamus (Teng et al. 2011).

The hypothalamus is a major central neuroendocrine regulation center involved in the control of energy homeostasis via orexigenic agouti-related peptide (AgRP)/ neuropeptideY (NPY)-producing neurons and anorexigenic proopiomelanocortin (POMC)-producing neurons (Bouyer \& Simerly 2013). Ablation of POMC neurons and loss of POMC-derived transmitters lead to obesity (Yaswen et al. 1999), further underscoring the importance of POMC neurons in regulation of energy homeostasis. Considering our reported findings that show high EpoR expression in hypothalamus, regulation of appetite and energy expenditure by exogenous Epo treatment in mice, and POMC induction in response to Epo treatment (Foskett et al. 2011, Teng et al. 2011), here we examine the regulation of hypothalamus POMC neuron function/response to Epo/EpoR signaling.

Leptin, a hormone secreted by adipose tissue into the circulation, binds its long-form receptor (LepRb) in the arcuate nucleus of the hypothalamus and activates signal transducer and activator of transcription 3 (STAT3), which positively regulates POMC expression (Bates et al. 2003). The largest population of LepRb-expressing neurons is in the hypothalamus (Zuure et al. 2013). Mice lacking leptin, $L e p R b$, or STAT3 genes become obese with a concomitant decrease in POMC expression (Gao et al. 2004, Diano et al. 2011, Harlan et al. 2011). Conversely, leptin treatment in mice reduced food intake and increased oxygen consumption (Coppari et al. 2005). Interestingly, Epo and leptin are both members of the hematopoietic cytokine superfamily and have similar protein structure (Ouyang \& He 2003, Fruhbeck 2006), receptor structure (Constantinescu et al. 2001, Mancour et al. 2012), and signaling mechanism (Banks et al. 2000, Zhang et al. 2014), and stimulate anorexic response after administration (Balthasar et al. 2004, Teng et al. 2011). Therefore, here we investigate potential links between Epo and leptin action, regulation of hypothalamus POMC neuron function/response to Epo/EpoR signaling, and potential cross talk between Epo and leptin signaling in POMC neurons.

\section{Materials and methods}

\section{Animal studies}

$\Delta \mathrm{EpoR}_{\mathrm{E}}$ mice were generated using the TgEpoR transgene consisting of EpoR cDNA driven by the GATA-1 locus erythroid regulatory domain (Suzuki et al. 2002) bred onto an EpoR null (EpoR ${ }^{-/-}$) background. This rescues the $E p o R^{-/-}$phenotype from severe anemia and death in utero (Suzuki et al. 2002). These $\Delta \mathrm{EpoR}_{\mathrm{E}}$ mice can survive through adulthood and their hematocrits are normal. The $\Delta$ EpoR $_{E}$ mice are on of C57BL/6 background and age-matched C57BL/6 WT mice were used as controls. For Epo treatment (3000 U/kg body weight; Epoetin alpha, Amgen, Thousand Oaks, CA, USA), the mice received s.c. injections three times at $0930 \mathrm{~h}$ per week. For leptin treatment $(5 \mathrm{mg} / \mathrm{kg}$ body weight; Peprotech, Rocky Hill, NJ, USA), mice received i.p. injection twice daily $(0930 \mathrm{~h}$ and $1730 \mathrm{~h}$ ) for three consecutive days. Mice were housed in individual cages for body weight and food intake studies, kept on $12 \mathrm{~h}$ light/darkness cycle, and fed normal chow diet. Studies were conducted following National Institutes of Health guidelines under institution-approved animal protocol.

\section{NPC cultures}

Embryos at 15.5 days (E15.5) were harvested from pregnant mice. The developing hypothalamus and cortex were dissected and transferred separately to serum-free media containing DMEM (with L-glutamine)/F12 (1:1) (Invitrogen) supplemented with B27 (Invitrogen), EGF (PeproTech, 20ng/ml), FGF-2 (PeproTech, $20 \mathrm{ng} / \mathrm{ml}$ ), and 0.5 units $/ \mathrm{ml}$ Pen-Strep (Invitrogen). Hypothalamus and cortex tissues were mechanically dissociated into single-cell suspension with a pipette. Cultures were also established from hypothalamus of newborn WT and $\Delta$ EpoR $_{\mathrm{E}}$ pups. Cell viability was assessed using trypan blue exclusion. Dissociated cells were cultured as an adherent monolayer and seeded on tissue culture plates pre-coated with $15 \mu \mathrm{g} / \mathrm{ml}$ poly-L-ornithine (PLO) (Sigma) and $1 \mu \mathrm{g} / \mathrm{ml}$ laminin (Sigma) with a seeding density of $1 \times 10^{5}$ cells $/ \mathrm{cm}^{2}$. After 7 days, cells reached around $90 \%$ confluency and were passaged at 1:4 to new plates and designated as passage 1 . Expansion cultures were passaged every 5 days regularly from first passage onward at 1:4 ratio and recorded as passage 2 through passage 10 .

\section{Quantitative RT-PCR}

Total RNA was extracted using RNeasy kit (Qiagen) and reverse transcribed using Molony Murine Leukemia virus

Published by Bioscientifica Ltd 
(MuLV) reverse transcriptase and the reagents from GeneAmp RNA PCR (Applied Biosystems). The SYBR green-I (Life Technologies)-based relative quantitative real-time PCR was performed on a 7900HT Thermocycler (Applied Biosystems). All primers were designed to span exon junctions in order to prevent the amplification of contaminating genomic DNA and $\beta$-Actin mRNA expression was used as a reference. The primer sequences are as follows: $m E p o R$-forward, ACGCTTGGAAGACTTGGTGTG; mEpoR-reverse, TGTTGGCAGTGAACACCAGAA; $P O M C$-forward, TTTCCTGGCAACGGAGA TGA; $P O M C$-reverse, CCACCGTAACGCTTGTCCTT; $N P Y$-forward, TCGTGTGTTTGGGCATTCTG; NPY-reverse, TCTGGTGATGAGATTGATGTAGTG; $A g R P$-forward, TGACTGC AATGTTGCTGAGTTGTG; $A g R P$-reverse, CTAGGTGCG ACTACAGAGGTTCG; $\beta$-Actin-forward, CAACGGCTCCGGCATGTGCAAAG, $\beta$-Actin-reverse, GGTGTGATGGTGGGAA TGGGTCAG; nestin-forward, AGAGATTGGAAGGCCG CTGG; nestin-reverse, CACCTTCCAGGATCTGAGCGA; $\beta$-tubulin-forward, GGGCCAAGTTCTGGGAGGTCATC; $\beta$-tubulin-reverse, GCACATACTTGTGAGAGGAGGCC.

\section{Western blotting}

For western blot analysis, NPC cultures were treated with Epo for 30 min to detect phosphorylated-STAT3 (p-STAT3), phosphorylated-JAK2 (p-JAK2), and phosphorylated-Akt (p-Akt) and for $24 \mathrm{~h}$ to detect POMC expression. Cells were lysed in RIPA buffer and protein was resolved on the basis of size in an NuPAGE electrophoresis system (Life Technologies). The primary antibodies used were anti-pSTAT3-Tyr705 (9131), anti-STAT3 (4904), anti-p-JAK2Tyr1007 (4406), anti-JAK2 (3230), anti- $\beta$-Actin (4967) (from Cell Signaling, Danvers, MA, USA), anti-POMC (ab14064), and anti-GAPDH (ab9485) (from Abcam). All antibodies were used at 1:1000 dilution. Either $\beta$-Actin or GAPDH protein expression was used to confirm equal protein loading between lanes.

\section{Immunofluorescence analysis}

After overnight fasting, mice were treated either with leptin, Epo, or saline at $0930 \mathrm{~h}$. After $90 \mathrm{~min}$, animals were anesthetized with isoflurane and perfused with ice-cold PBS via the heart and then fixed with $100 \mathrm{ml}$ of $4 \%$ paraformaldehyde (PFA) solution (Sigma). Brain was removed, post-fixed overnight in 4\% PFA, followed by overnight cryoprotection in 30\% sucrose, and cut in $10-\mu \mathrm{m}$ coronal sections, collected in five series. Immunostaining was done on serial sections with $\alpha$-MSH antibody
(20074, Immunostar, Hudson, WI, USA) at 1:4000 dilution and counterstained with DAPI for nuclear staining. Alexa Fluor 488-conjugated goat anti-rabbit IgG (Abcam) was used as a secondary antibody. The saline-treated group served as a negative control and tested antibody specificity. For staining NPC cultures, passage 3 cells were grown in cover slips coated with PLO and laminin as described above for NPC culture, and fixed with 4\% PFA for $20 \mathrm{~min}$. Due to variability in commercial lots of EpoR polyclonal antibody, we used the MAB developed at Genetics Institute against the EpoR extracellular domain (mh2er.16.5.1) that previously provided consistent results for immunohistochemistry and has been characterized for specificity (D'Andrea et al. 1993, Anagnostou et al. 1994, Teng et al. 2011). Anti-EpoR antibody was used at 1:25 dilution. Passage 1 NPC cells were also used as a negative control for EpoR staining. To detect POMC expression, cells were stained using POMC antibody (H-029-30, Phoenix Pharmaceuticals, Burlingame, CA, USA) at 1:1000 dilution. For fluorescent detection of POMC and EpoR, Alexa488conjugated goat anti-rabbit IgG and Alexa594-conjugated goat anti-mouse IgG respectively (Abcam) were used.

\section{Statistical analysis}

Differences among groups were analyzed by ANOVA with post-hoc comparison by Student's $t$ test for continuous variables and $\chi^{2}$ or Fisher's exact test for nominal variables, as appropriate, followed by Bonferroni correction for multiple comparisons. All results are reported as mean \pm S.D. from at least three independent experiments. In all cases, $P<0.05$ was considered to be statistically significant.

\section{Results}

\section{Primary hypothalamus NPC cultures express POMC and EpoR}

We previously reported that EpoR protein in mouse hypothalamus localizes to POMC-expressing neurons, and Epo directly regulates POMC expression in these neurons (Teng et al. 2011). To study Epo/EpoR-mediated regulation of POMC in mouse hypothalamus, we established NPC cultures from E15.5 mouse hypothalamus. For comparison, primary NPCs derived from E15.5 hippocampus and cortex were used because these brain regions also express EpoR (Yu et al. 2002, Chen et al. 2007). POMC expression in the respective cultures, determined by quantitative RT-PCR, revealed that POMC mRNA was mainly expressed in hypothalamus-derived NPC cultures

Published by Bioscientifica Ltd 
and ten times higher than levels detected in cultures derived from cortex or hippocampus (Fig. 1A). In contrast, EpoR mRNA expression was readily detected in NPC cultures from each of these three regions with expression highest in the hippocampus. The levels in the hypothalamus were one-half to one-third the levels in the hippocampus or cortex (Fig. 1B).
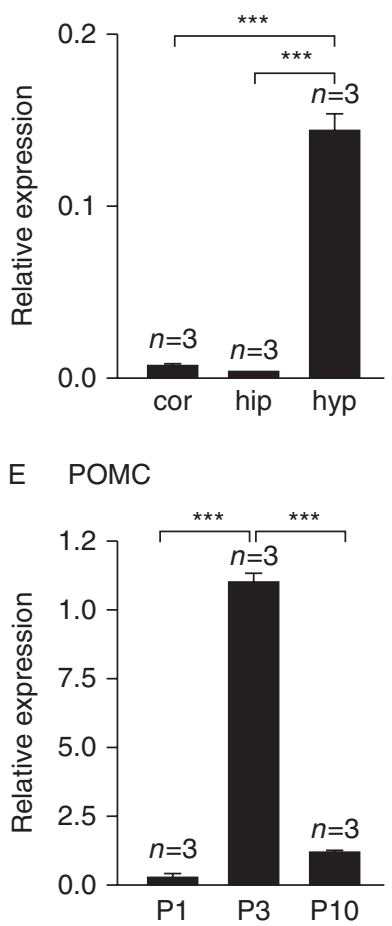

$\mathrm{H}$



B EpoR

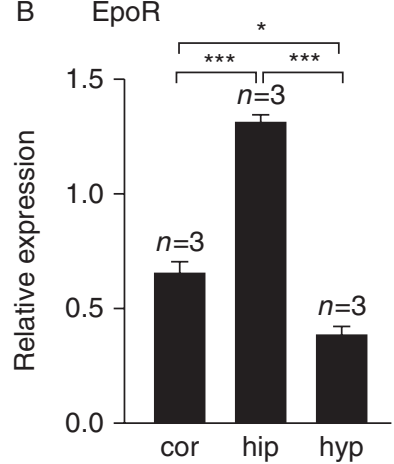

F

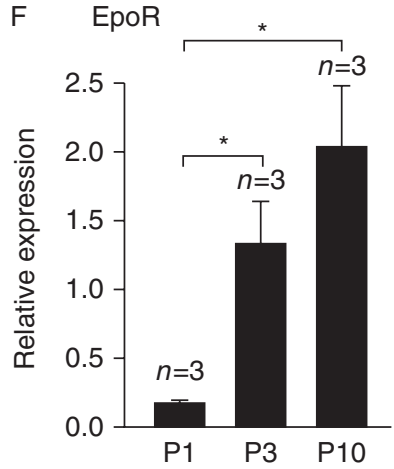

EpoR

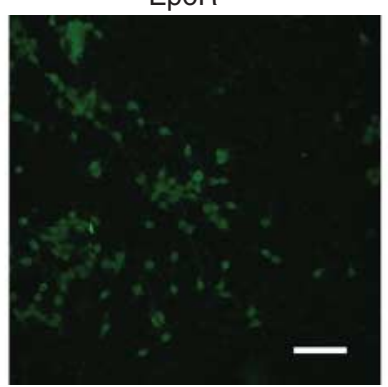

NPC cultures as an adherent monolayer are prone to density-dependent differentiation. Adherent NPC cultures were passaged when confluence was $>90 \%$ to promote density-dependent differentiation. With increasing passage, nestin mRNA expression decreased by more than an order of magnitude (Fig. 1C) while $\beta$-tubulin mRNA expression increased between passage 1 and passage 3
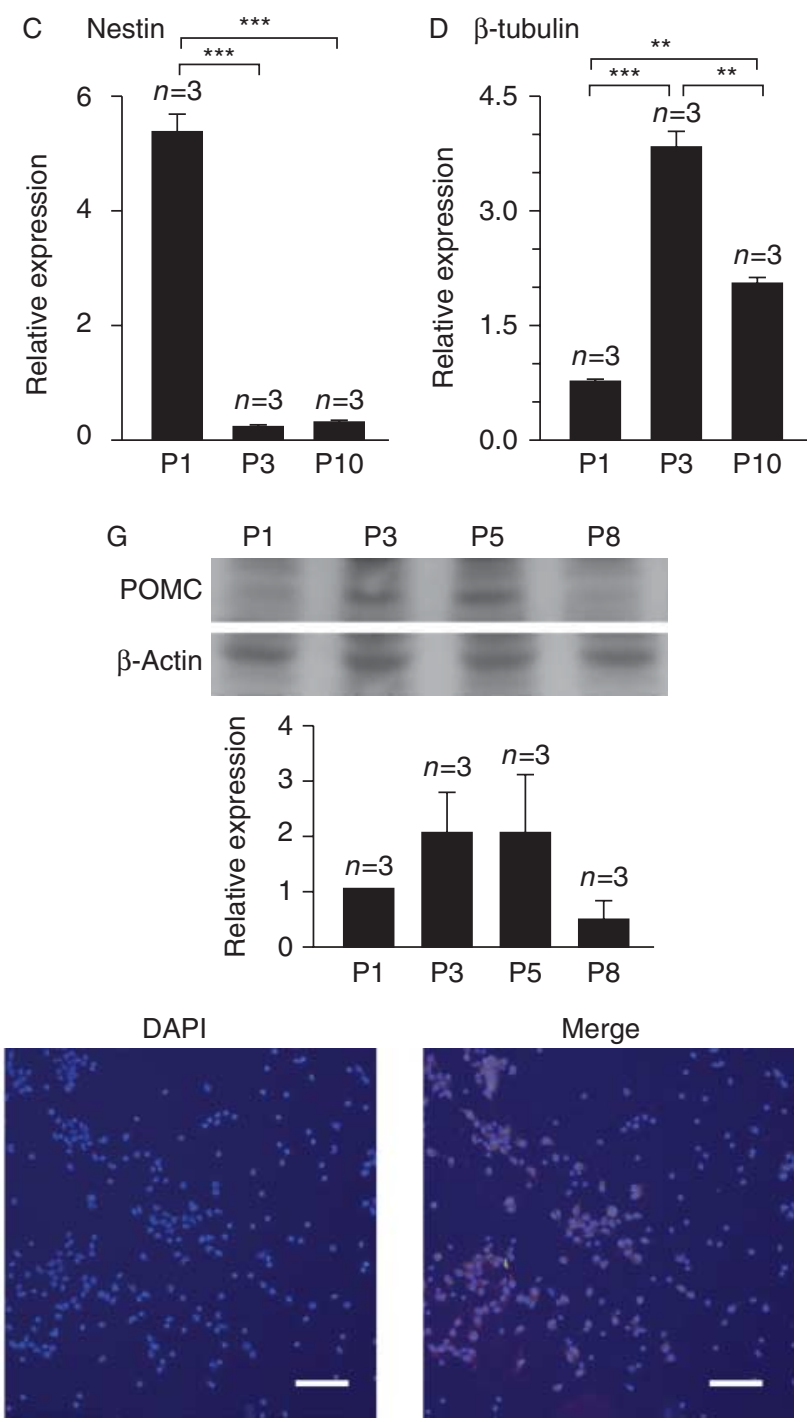

\section{Figure 1}

Gene expression in primary neural progenitor cell (NPC) cultures from WT hypothalamus. (A and B) POMC (A) and EpoR (B) mRNA levels in NPCs derived from embryonic day E15.5 cortex (cor), hippocampus (hip), and hypothalamus (hyp) from WT mice as measured by quantitative real-time (RT) PCR and normalized to $\beta$-Actin mRNA levels. (C, D, E and F) Quantification of nestin (C), $\beta$-tubulin (D), POMC (E), and EpoR (F) mRNA levels in hypothalamus NPC culture at passages 1,3 , and 10 relative to $\beta$-Actin mRNA levels as determined by RT-PCR. Reactions were run in triplicate and results are representative of three independent experiments (G) western blotting for POMC (top panel) and $\beta$-Actin (middle panel) protein expression, and quantitative densitometry analysis (lower panel) at passages 1, 3, 5, and 8 of hypothalamus NPC cultures are shown.

Densitometry data is representative of three independent experiments. Statistical significance is indicated by $* P<0.05, * * P<0.01$, and $* * * P<0.001$ (one-way ANOVA followed by Bonferroni correction). (H) Double fluorescent immunostaining for POMC (green) and EpoR (red) on hypothalamus NPC cultures at passage 3 and stained with DAPI staining (blue) for nuclei and merged for triple stained image. Scale bar represents $100 \mu \mathrm{m}$ http://jme.endocrinology-journals.org DOI: 10.1530/JME-15-0171
(C) 2016 Society for Endocrinology Printed in Great Britain 
(Fig. 1D), indicating a shift from NPCs to immature neurons concomitant with an increase in $P O M C$ and EpoR mRNA expression (Fig. 1E and F). POMC protein production examined by western blotting increased between passage 1 and passage 3, was maximal between passages 3 and 5 , and then decreased by passage 8 (Fig. 1G). These data suggest that the increase in POMC expression and protein production in these cultures correlates with a shift in nestin-expressing NPCs toward $\beta$-tubulin- and POMC-expressing immature neurons with a maximal shift occurring between passages 3 and 5. At passage 10, EpoR mRNA continued to be expressed, but $\beta$-tubulin and POMC mRNA levels declined (Fig. 1D and E). Immunostaining of passage 3 cells also showed colocalization of POMC and EpoR protein expression and the presence of cells that did not stain for either, suggesting EpoR expression is specific for POMC neurons in this population of cells (Fig. 1H). These POMC- and EpoR-expressing cells comprised $\sim 50 \%$ of total cell population in culture at this stage. Moreover, there were no cells that expressed EpoR only, and not POMC. Immunostaining of passage 1 cells with anti-POMC and anti-EpoR antibodies served as negative controls and confirmed the specificity of these antibodies. The apparent patterns of cytoplasmic anti-EpoR staining in POMC neurons may relate to the processing and trafficking of EpoR and the reported observations that only a minor fraction of the Golgi-processed receptor is on the cell surface and a few high affinity Epo surface binding receptors in neuronal cells are sufficient for Epo-activated cell signaling (Hilton et al. 1995, Um et al. 2007). In all subsequent experiments, cells from passages 3 to 5 which showed optimum POMC and EpoR expression were used. In cortex-derived NPC cultures, the low level of POMC expression did not increase with time in passage indicating that cortex-derived NPCs did not exhibit the ability to self-differentiate into POMC-expressing neurons (data not shown).

\section{Epo increases POMC expression in hypothalamus NPC cultures via JAK2/STAT3 pathway}

Epo treatment of hypothalamus NPC cultures increased POMC mRNA expression in a dose-dependent manner as determined by quantitative RT-PCR (Fig. 2A). Similar increase in POMC protein expression was also observed as determined by western blotting (Fig. 2B). In addition to regulating POMC, Epo treatment increased JAK2- and STAT3-phosphorylation in NPC cultures (Fig. 2C). Pretreatment with STAT3 inhibitor WP1066 $(3 \mu \mathrm{M})$ for
30 min was sufficient to abrogate Epo induction of POMC (Fig. 2D). While $\beta$-tubulin expression did not change with Epo treatment, there was a modest decrease (10\% or less) in $\beta$-tubulin with WP1066 treatment with and without Epo (Fig. 2F). These results suggest that STAT3 phosphorylation is required for Epo induction of POMC and that inhibition of STAT3 phosphorylation by WP1066 decreases POMC expression by reducing the amount of POMC expression with minimal change in $\beta$-tubulin and the proportion of cells with the potential to express POMC. Epo treatment of hypothalamus NPC cultures at 10 and $20 \mathrm{U} / \mathrm{ml}$ also resulted in a small but significant increase in cell number in a dose-dependent manner at both $32 \mathrm{~h}$ and $48 \mathrm{~h}$ of treatment (Fig. 2F).

\section{Loss of EpoR signaling in hypothalamus NPC cultures affects their leptin response}

We previously reported that leptin is not required for the effects of exogenous Epo treatment on body weight and fat mass loss (Teng et al. 2011). However, Epo signaling in NPC is mediated via STAT3 pathway (Fig. 2), which is also activated in the arcuate nucleus after leptin treatment. Whether Epo/EpoR signaling affects leptin response in hypothalamus was unknown. To investigate this question, hypothalamus-derived NPC cultures were generated from neonate WT and $\Delta \mathrm{EpoR}_{\mathrm{E}}$ mice. With leptin and Epo treatment, WT cultures showed an increase in STAT3 phosphorylation (Fig. 3A). In contrast, NPC cultures from $\triangle$ EpoR $_{\mathrm{E}}$ mice did not show the increase in STAT3 phosphorylations expected with Epo treatment (Fig. 3A). Interestingly, $\triangle \mathrm{EpoR}_{\mathrm{E}}$ hypothalamus cultures also did not exhibit the expected increase in STAT3 phosphorylation with leptin treatment (Fig. 3A). Of note, baseline levels of STAT3 phosphorylation were lower in $\Delta \mathrm{EpoR}_{\mathrm{E}}$ hypothalamus NPC cultures compared to those from WT hypothalamus (comparing saline treatment lanes, Fig. 3A). Moreover, Epo and leptin combination treatments were not more effective than Epo or leptin treatment alone in inducing STAT3 phosphorylation (Fig. 3A). Consistent with STAT3 activation, $24 \mathrm{~h}$ treatment with either leptin or Epo increased POMC mRNA expression in WT hypothalamus cultures by two- to 2.5-fold, with combination treatment no better than individual treatment conditions (Fig. 3B). In $\triangle$ EpoR $_{\mathrm{E}}$ hypothalamus cultures, baseline POMC mRNA expression appeared to be fourfold lower than WT cultures, but was induced approximately twofold by leptin or the combination of leptin plus Epo treatment, but not by Epo alone (Fig. 3B). Note that even with leptin treatment,

Published by Bioscientifica Ltd. 
A

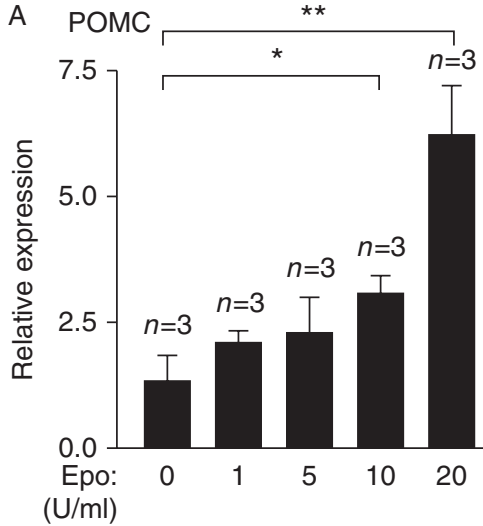

$(\mathrm{U} / \mathrm{ml})$

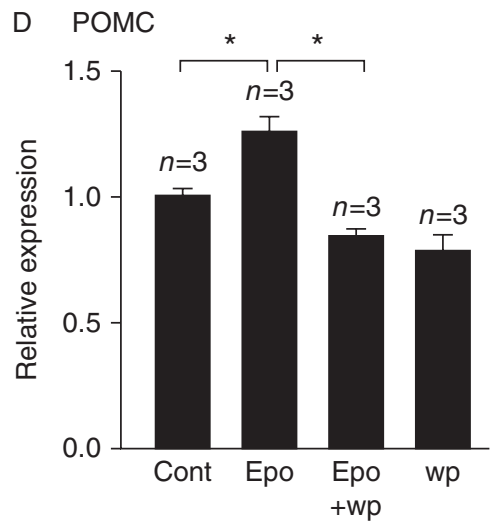

B
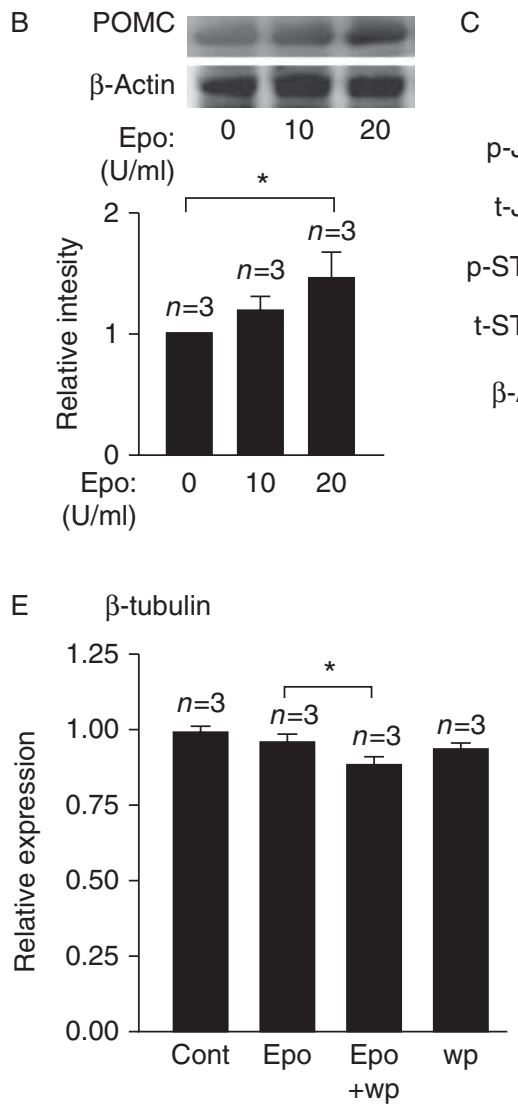

C
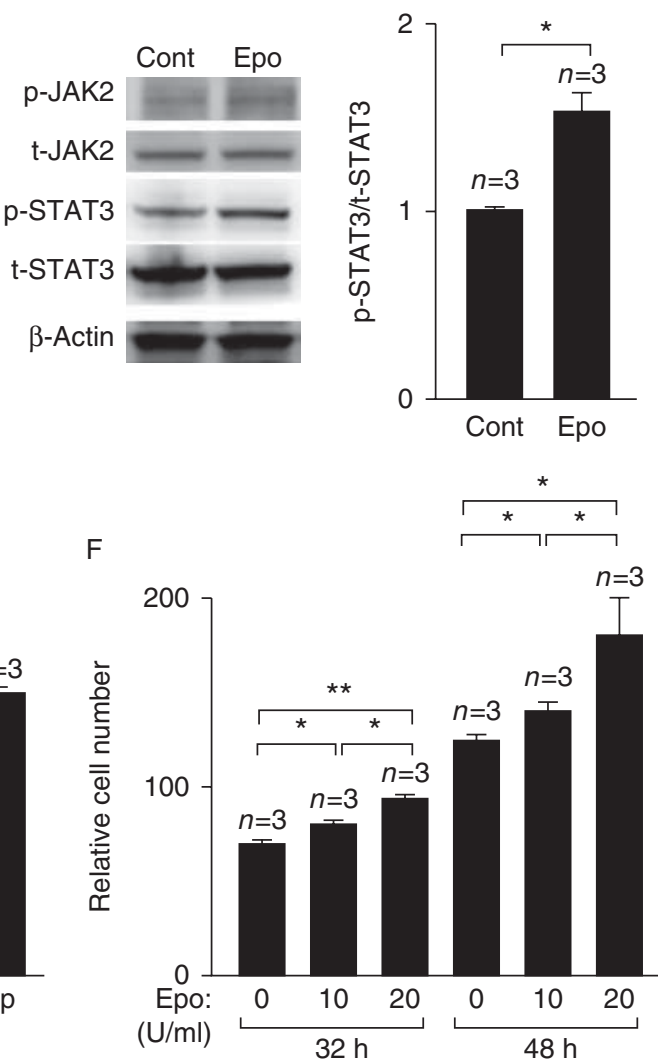

\section{Figure 2}

Epo treatment induces proliferation, POMC expression, and JAK2 and STAT3 signaling in WT hypothalamus NPC culture. (A and B) Dosedependent increase in POMC mRNA levels relative to untreated cells and adjusted to $\beta$-Actin mRNA levels (A), and POMC protein normalized to $\beta$-Actin after 24 h of Epo-treatment (B) were determined. Densitometry data is representative of three independent experiments. (C) Western blotting for phosphorylated-JAK2 ( $p$-JAK2), total JAK2 (t-JAK2), phosphorylatedSTAT3 (p-STAT3), total STAT3 (t-STAT3), and $\beta$-Actin protein in control- and Epo-treated $(20 \mathrm{U} / \mathrm{ml})$ NPC cultures, and quantitative densitometry analysis of band intensity ratio of p-STAT3 and t-STAT3 are shown. Densitometry data

$P O M C$ expression in $\triangle \mathrm{EpoR}_{\mathrm{E}}$ cultures was only half the level of control-treated WT cultures (Fig. 3B), and no significant induction in STAT3 phosphorylation was detected (Fig. 3A). Conversely, NPY and AgRP mRNA expression did not show any difference between WT and $\triangle$ EpoRE hypothalamus NPC cultures, and was reduced similarly by leptin treatment only (Fig. 3C and D). Combination treatment or Epo alone did not affect either $N P Y$ or $A g R P$ mRNA expression (Fig. 3C and D). These data support the previous finding that EpoR expression is specific for POMC neurons (Teng et al. 2011) and lack of EpoR neither affect NPY and AgRP expression nor its response after leptin treatment. These observations collectively point to an important and previously unrecognized is representative of three independent experiments. (D and E) Level of POMC (D) and $\beta$-tubulin (E) mRNA as measured by RT-PCR analysis of NPCs after saline treatment (Cont), Epo treatment, Epo with STAT3 inhibitor WP1066 and WP1066 only. The mRNA expression levels are relative to salinetreated (Cont) cells and adjusted to $\beta$-Actin mRNA levels, and represents mean \pm s.D. from triplicate reactions. (F) Proliferation of NPC cultures after $32 \mathrm{~h}$ and $48 \mathrm{~h}$ of Epo treatment at $0-, 10-$, and $20-\mathrm{U} / \mathrm{ml}$ doses. Relative cell numbers are representative of triplicate treatments for each dose. Statistical significance is indicated by $* P<0.05$ and $* * P<0.01$ (one-way ANOVA followed by Bonferroni correction).

role for EpoR signaling to contribute to leptin response in hypothalamus NPC ex vivo. Interestingly, LepRb mRNA levels showed a small but significant reduction in $\Delta \mathrm{EpoR}_{\mathrm{E}}$ cultures compared to the WT (Fig. 3E), but cell proliferation during the NPC culture is not affected by loss of EpoR (Fig. 3F).

\section{Absence of hypothalamus EpoR signaling reduces in vivo STAT3 phosphorylation and POMC production, blunts leptin-induced STAT3 activation but not the leptin-induced relative increase of POMC}

Ex vivo hypothalamus NPC cultures provided evidence for Epo-stimulated STAT3-activation (Figs 2 and 3). Loss 


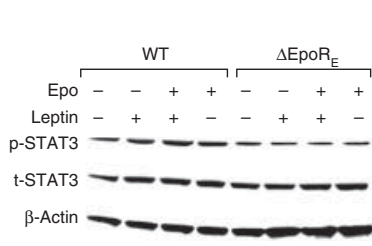

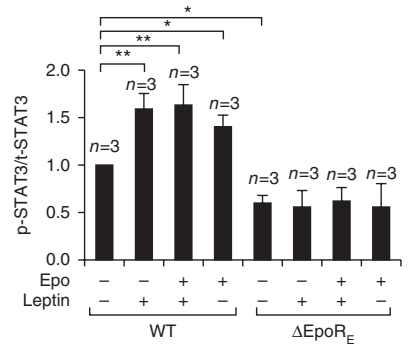



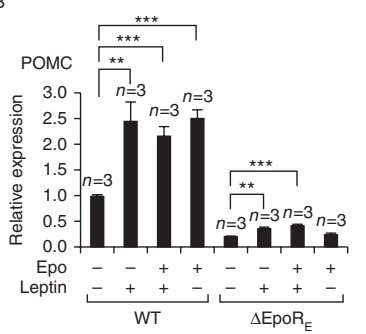

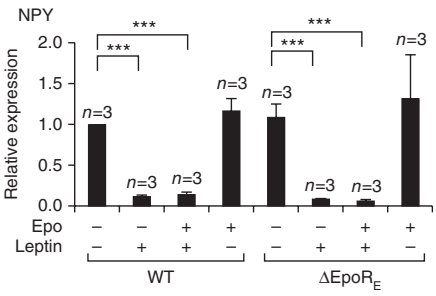



Figure 3

EpoR signaling is required for optimum leptin response in NPC cultures. (A) Western blotting and quantitative densitometry analysis were used to determine levels of phosphorylated-STAT3, total-STAT3, and $\beta$-Actin protein levels (A), in WT and $\triangle E p o R_{E}$ NPC cultures after control saline treatment, Epo treatment, Epo + leptin treatment, and leptin treatment. Epo and leptin was used at $20 \mathrm{U} / \mathrm{ml}$ and $1000 \mathrm{U} / \mathrm{ml}$ respectively and densitometry analysis is representative of three independent experiments (B, C and D) POMC (B), NPY (C), and AgRP (D) mRNA expression in WT and $\triangle E_{p o R_{E}} N P C$ cultures were determined after Epo, Epo+ leptin, and leptin

of endogenous Epo activity in $\Delta \mathrm{EpoR}_{\mathrm{E}}$ hypothalamus should also reduce STAT3 phosphorylation in vivo. $\Delta$ EpoR $_{\mathrm{E}}$ mice show age-dependent obesity, and at 8 months are $30 \%$ or greater in body mass vs WT due to increased fat mass with a corresponding increase in circulating leptin levels (Teng et al. 2011). To avoid this apparent obesity related increase in leptin level and the expected change in STAT3 phosphorylation related to increased leptin signaling, we examined hypothalamus STAT3 phosphorylation in young mice prior to development of fat tissue. At postnatal day 2-3, STAT3 phosphorylation in the hypothalamus of $\Delta \mathrm{EpoR}_{\mathrm{E}}$ mice was reduced by threefold compared with WT mice while levels of total STAT3 were comparable (Fig. 4A). The difference in STAT3 phosphorylation was also evident in $\Delta \mathrm{EpoR}_{\mathrm{E}}$ mice at postnatal day 4-5 (Fig. 4B).

Regulation of body weight involves a balance between energy intake and energy expenditure. Leptin has the ability to decrease food intake, increase energy expenditure and promote body weight loss. We investigated whether the changed energy balance of $\Delta \mathrm{EpoR}_{\mathrm{E}}$ mice involved alterations in leptin-mediated signaling in the hypothalamus (Fig. 4C and F). Three-week old mice were used to eliminate possible leptin resistance associated with treatments, relative to control saline-treated WT cells. (E) LepRb mRNA expression in WT and $\triangle E_{\text {Epo }}$ NPC cultures. Gene expressions were adjusted to $\beta$-Actin mRNA levels and RT-PCR reactions were run in triplicate. (F) Fold change in numbers of NPC from WT and $\triangle E$ EpoR $R_{E}$ E15.5 embryos. PO represents cell proliferation from day 1 to day 7 of culture, and P1-P5 represents passages $1-5$ after every 5 days. Fold change is representative of three independent experiments. Statistical significance is indicated by $* P<0.05, * * P<0.01$ and $* * * P<0.001$ (one-way ANOVA followed by Bonferroni correction).

older, obese $\Delta \mathrm{EpoR}_{\mathrm{E}}$ mice, and also to ensure complete development of neurons of the arcuate nucleus. $\Delta \mathrm{EpoR}_{\mathrm{E}}$ hypothalamus showed a lower level of STAT3 phosphorylation compared to WT hypothalamus (Fig. 4C). However, the difference is reduced compared with mice at postnatal days 2-3 (Fig. 4A) and days 4-5 old (Fig. 4B). This suggests that $\Delta \mathrm{EpoR}_{\mathrm{E}}$ mice by 3 weeks develop a compensatory mechanism that restores STAT3 phosphorylation closer to normal WT levels. In contrast to ex vivo $\Delta \mathrm{EpoR}_{\mathrm{E}}$ hypothalamus cultures that show no leptin-induced STAT3 phosphorylation (Fig. 3A), $\Delta$ EpoR $_{\mathrm{E}}$ mice exhibited a blunted in vivo leptin-induced STAT3 phosphorylation in hypothalamus compared with WT mice (Fig. 4C). This suggests that, in vivo, other mechanisms attempt to compensate for the apparent loss of direct leptin induction of STAT3 phosphorylation in hypothalamus NPC derived cells.

In vivo, baseline POMC protein levels were lower in $\triangle$ EpoR $_{\mathrm{E}}$ mice, analogous to the reduced POMC mRNA in $\Delta$ EpoR $_{\mathrm{E}}$ hypothalamus cultures (Fig. 3B), and leptin could induce POMC expression only up to baseline WT levels (Fig. 4D). These data suggest that in vivo leptin response in $\Delta$ EpoR $_{\mathrm{E}}$ hypothalamus is blunted with respect to STAT3 phosphorylation, and the reduction in baseline STAT3 
A

\section{Post natal day 2-3}
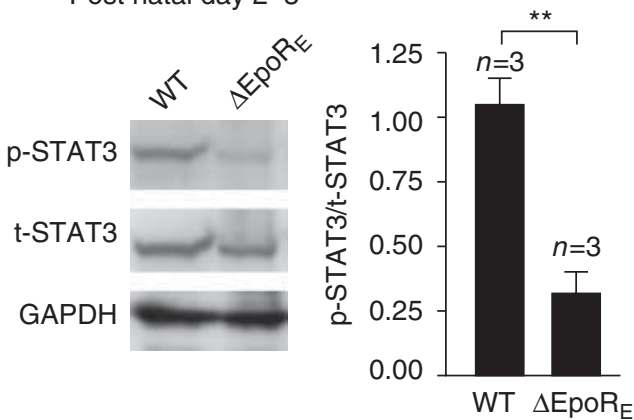

C 3 week old mice

\begin{tabular}{|c|c|c|c|}
\hline \multicolumn{2}{|c|}{ WT } & \multicolumn{2}{|c|}{$\Delta \mathrm{EpoR}_{\mathrm{E}}$} \\
\hline Saline & Leptin & Saline & Leptin \\
\hline
\end{tabular}
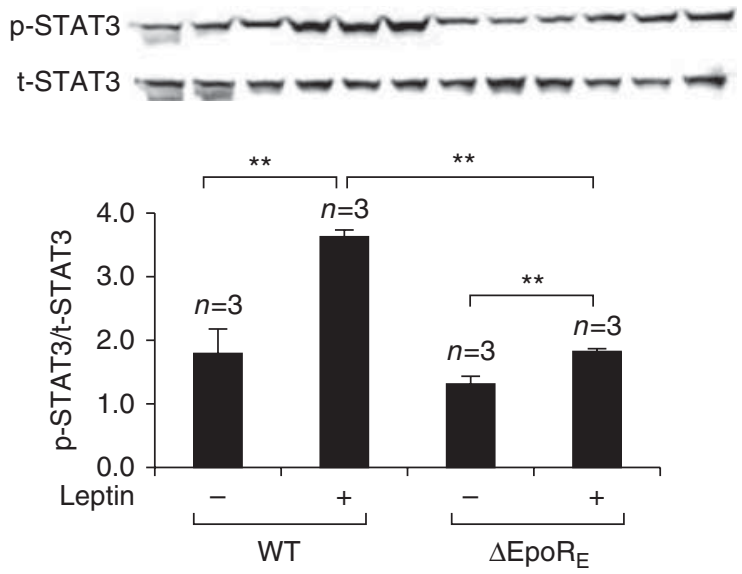

E 3 week old mice

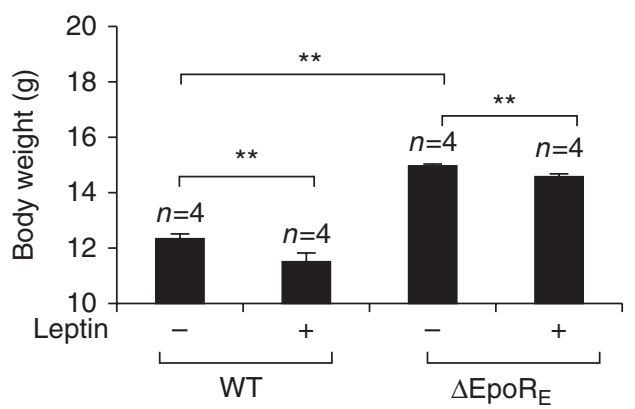

Figure 4

$\triangle$ EpoR $_{\mathrm{E}}$ mice show blunted STAT3 activation but equivalent POMC induction in the hypothalamus after leptin treatment compared to WT mice. (A and B) Western blotting and quantitative densitometry analysis (from three pups each of WT and $\triangle E$ EPORE $R_{E}$ were used to compare phosphorylated-STAT3 ( $p$ STAT3), total-STAT3 (t-STAT3), and GAPDH protein levels in WT and $\triangle$ Epo $_{E}$ pups at postnatal day 2-3 (A) and postnatal day 4-5 (B). (C and D) Western blotting and quantitative densitometry analysis demonstrating

activation results in a lower level of POMC in $\Delta \mathrm{EpoR}_{\mathrm{E}}$ mice, compared with WT mice without and with leptin treatment. Leptin induction of POMC in both WT and $\Delta \mathrm{EpoR}_{\mathrm{E}}$ mice was also reflected in a small but significant
B Post natal day $4-5$

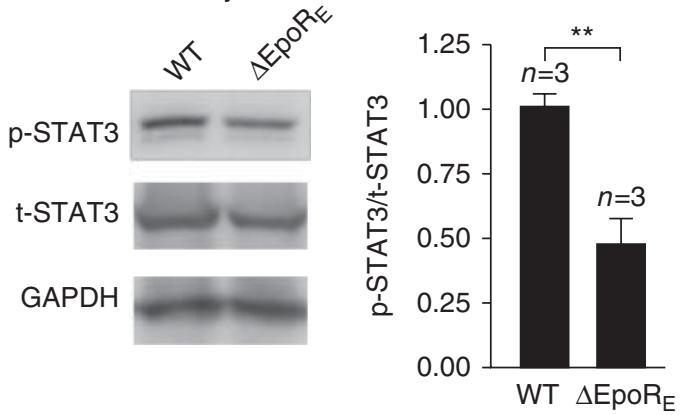

D 3 week old mice



F 3 week old mice

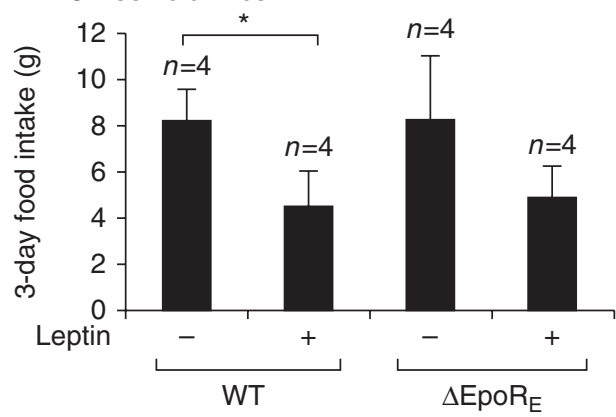

phosphorylated-STAT3 (p-STAT3) and total-STAT3 (t-STAT3) (C), POMC and GAPDH (D) in a 3-week-old female WT and $\triangle$ EpoR $_{\mathrm{E}}$ mice 45 min after treated with leptin ( $5 \mathrm{mg} / \mathrm{kg}$ body weight) or saline ( $n=3$ for each treatment group). ( $E$ and $F$ ) Body weight $(E)$, and food intake (F) were determined in WT and $\triangle E p o R_{E}$ mice after saline- or leptin-treatment twice daily for 3 days $(n=4$ for each treatment group). Statistical significance is indicated by $* P<0.05$, and $* * P<0.01$ (one-way ANOVA followed by Bonferroni correction).

decrease in body weight after leptin treatment in WT mice (6\%) and in an apparent smaller decrease in $\Delta \mathrm{EpoR}_{\mathrm{E}}$ mice (2.5\%) (Fig. 4E). Food intake for 3 days was significantly lower in leptin-treated WT mice, and also showed a 
reduced trend in $\Delta$ EpoR $_{\mathrm{E}}$ mice (Fig. $4 \mathrm{~F}$ ). In summary, these data suggest that loss of EpoR in young mice reduces baseline hypothalamus STAT3 activation and lowers POMC expression in the hypothalamus. Moreover, leptin sensitivity with respect to body weight loss and reduced food intake are still evident in $\Delta \mathrm{EpoR}_{\mathrm{E}}$ mice.

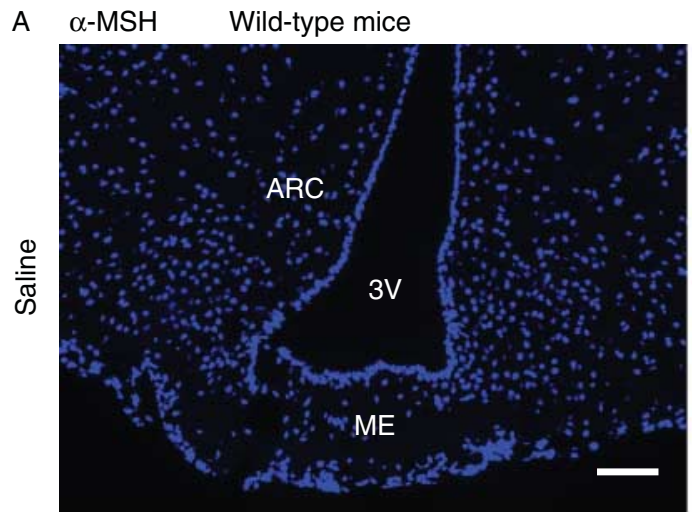

\section{C $\alpha-\mathrm{MSH}$}
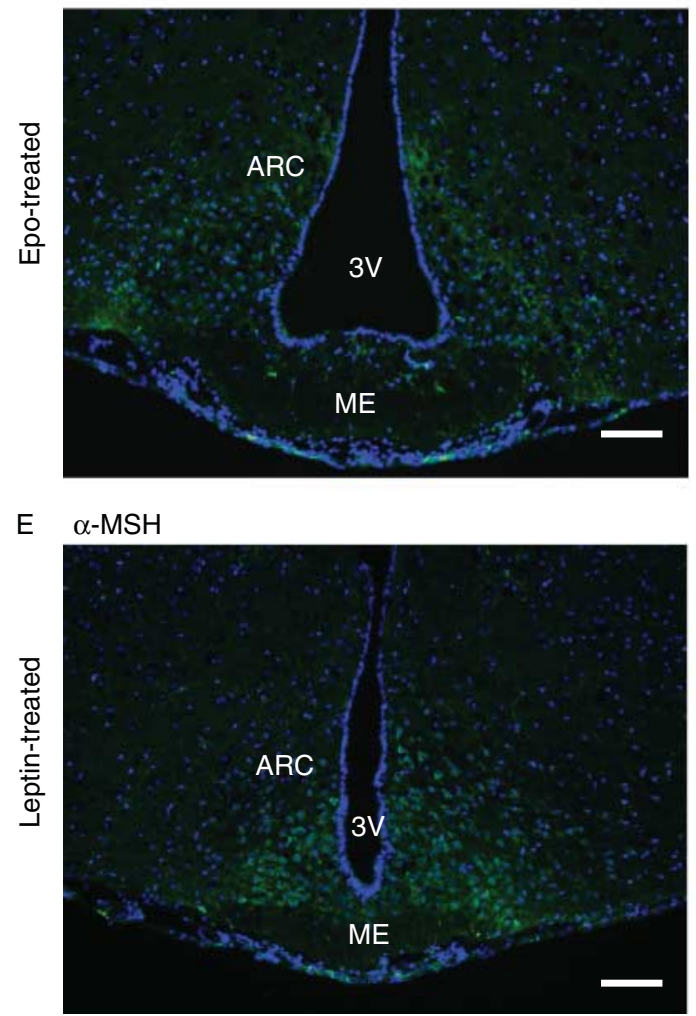

\section{Figure 5}

Induction of $\alpha-\mathrm{MSH}$, a POMC product, in the arcuate nucleus region of the mouse brain after either saline, Epo, or leptin treatment. Representative fluorescence photomicrographs for $\alpha$-MSH immunoreactivity in brain sections prepared from the mouse mediobasal hypothalamus consisting of the arcuate nucleus region are shown. Three-week old female WT

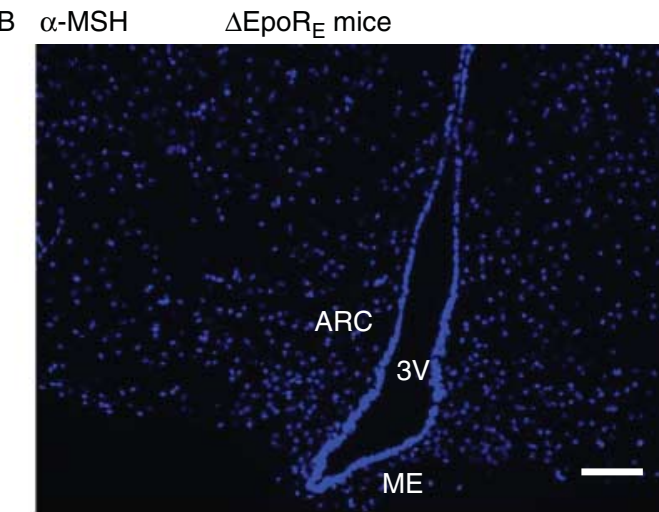

Finally, immunohistochemical staining of brain sections displaying the arcuate nucleus region of the hypothalamus also showed lower staining for $\alpha$-MSH, a cleavage product of POMC, in $\Delta \mathrm{EpoR}_{\mathrm{E}}$ mice compared to WT mice (Fig. 5A and B). Both Epo and leptin treatment of WT mice induced $\alpha$-MSH expression (Fig. 5C and E).

D $\alpha-M S H$

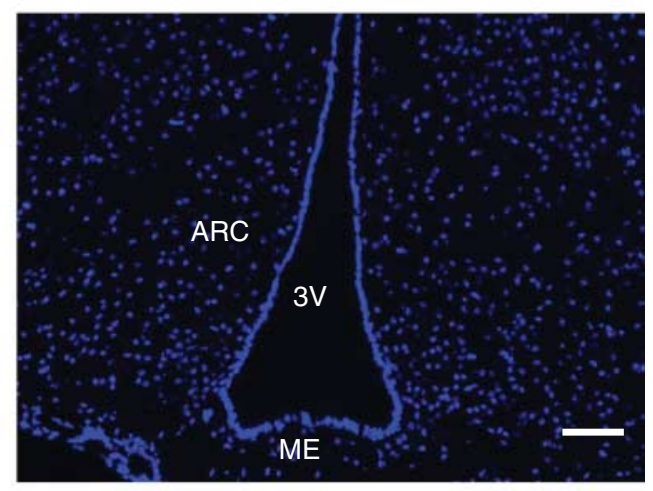

F $\alpha-M S H$

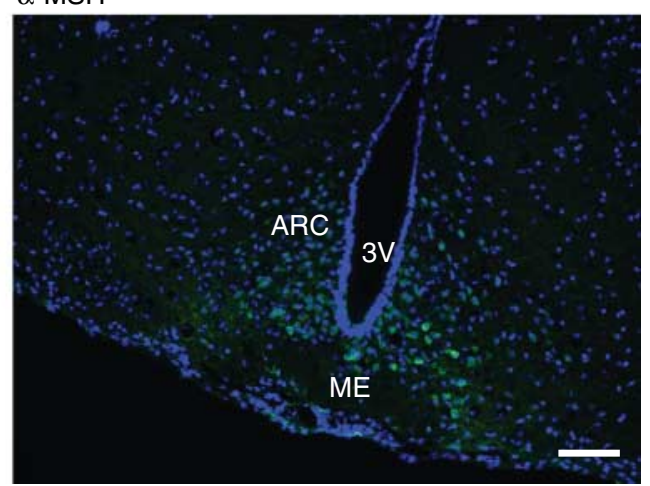

( $A, C$ and $E$ ) or $\triangle$ EpoRE ( $B, D$ and $F$ ) mice were treated with either saline ( $A$ and $B$ ), Epo (3000 U/kg body weight) ( $C$ and $D)$, or Leptin $(5 \mathrm{mg} / \mathrm{kg}$ body weight) ( $E$ and F). Scale bar represents $100 \mu \mathrm{m}$. 3V, third ventricle; ARC, arcuate nucleus; ME, median eminence.

Published by Bioscientifica Ltd 
As expected, the $\Delta$ EpoR $_{E}$ mice brain sections showed higher immunoreactivity to $\alpha$-MSH only after leptin treatment and not Epo treatment (Fig. 5D and F).

\section{Discussion}

EpoR is expressed in the POMC neurons of the hypothalamus, a master regulatory site of appetite and energy expenditure, and the increased POMC expression in Epotreated WT mice suggested that Epo could directly stimulate these POMC neurons (Teng et al. 2011), although the detailed mechanism of POMC neuron response to Epo was uncertain. We previously showed that Epo treatment in WT mice decreases body weight and fat mass by reducing food intake and increasing energy expenditure (Foskett et al. 2011, Teng et al. 2011). While EpoR is expressed in several brain regions including hypothalamus, hippocampus and cortex, NPC cultures from the hypothalamus show unique induction of POMC expression with Epo treatment. Using hypothalamusderived NPC cultures, we studied the signaling pathways activated by Epo in POMC neurons and investigated the crosstalk between LepRb and EpoR signaling.

Epo and leptin are both members of the class-I cytokine superfamily (Ouyang \& He 2003, Fruhbeck 2006) and act through the JAK/STAT signaling pathway (Constantinescu et al. 2001, Mancour et al. 2012). Leptin stimulation of POMC expression in the hypothalamus is mediated via STAT3 activation (Bates et al. 2003) and we found that Epo-stimulated increase of POMC is also dependent on STAT3 activation. The requirement for EpoR for normal hypothalamus response is further confirmed by analysis of hypothalamus from $\Delta \mathrm{EpoR}_{\mathrm{E}}$ mice with EpoR expression restricted to erythroid tissue. Neonatal $\Delta$ EpoR $_{\mathrm{E}}$ mice show reduced STAT3 phosphorylation and lower level of POMC expression in the hypothalamus compared with WT mice. In addition, corresponding hypothalamus NPC cultures from $\triangle$ EpoR $_{\mathrm{E}}$ mice lack activation of STAT3 or induction of POMC with Epo treatment. Evidence that loss of EpoR may blunt the leptin response is further suggested by ex vivo findings from $\Delta \mathrm{EpoR}_{\mathrm{E}}$ hypothalamus cultures that also exhibit loss of leptin-induced increase in STAT3 phosphorylation. These data provide evidence that endogenous Epo signaling in WT hypothalamus contributes to STAT3 phosphorylation while loss of Epo signaling reduces endogenous baseline level of STAT3 activation and POMC production. The reduction in endogenous STAT3 activity in $\Delta \mathrm{EpoR}_{\mathrm{E}}$ mice is consistent with the severe obese phenotype observed in mice with neural-specific disruption of STAT3 that underscore its importance in the CNS in regulating energy homeostasis (Gao et al. 2004). Interestingly, with leptin treatment in the $\Delta$ EpoR $_{\mathrm{E}}$ mice, induction of STAT3 phosphorylation in the hypothalamus is reduced to half that in treated WT mice. While the low level of POMC expression in $\triangle \mathrm{EpoR}_{\mathrm{E}}$ hypothalamus is increased with leptin treatment and fold induction of POMC in $\triangle \mathrm{EpoR}_{\mathrm{E}}$ and WT hypothalamus are similar, the level of POMC remains $50 \%$ or less than treated WT hypothalamus. The lack of leptin induced STAT3 activation observed in $\Delta$ Epo $_{\mathrm{E}}$ hypothalamus cultures suggests that other Epo-independent signaling pathways compensate in part to provide leptin induced POMC expression in $\triangle \mathrm{EpoR}_{\mathrm{E}}$ hypothalamus. Epo influence on leptin-responsive weight loss is also suggested by the lower percentage weight decrease in $\Delta$ EpoR $_{\mathrm{E}}$ mice.

The finding that leptin requires functional EpoR for normal levels of STAT3 activation and POMC induction in hypothalamus provides an explanation for the low POMC levels in hypothalamus of $\Delta \mathrm{EpoR}_{\mathrm{E}}$ mice despite elevated circulating leptin levels and for the resultant altered energy homeostasis (Teng et al. 2011), and suggests disruption of critical leptin regulation of energy efficiency in the hypothalamus. However, a combination of Epo/ leptin treatment did not induce higher POMC expression, which raises the possibility that Epo may prime POMC neurons in the hypothalamus for subsequent leptin action, and the kinetics of treatment is critical to see a combined Epo/leptin effect on POMC expression. Although lack of EpoR does not affect NPC proliferation in culture, LepRb expression is modestly reduced in $\Delta \mathrm{EpoR}_{\mathrm{E}}$ NPC cultures. This raises the possibility that EpoR signaling is required for the complete maturation of POMC neurons without affecting its numbers.

These data suggest that direct response by the hypothalamus to Epo treatment contributes, in part, to regulation of body weight and fat mass via STAT3 activation and POMC induction. The $\triangle \mathrm{EpoR}_{\mathrm{E}}$ mice provide further evidence that increased metabolic load of Epo-stimulated erythropoiesis cannot explain the body weight reduction after Epo treatment in WT mice. Specifically, $\Delta$ EpoR $_{\mathrm{E}}$ mice treated with Epo exhibit the expected increase in hematocrit, but without the significant reduction in body mass observed in WT mice (Teng et al. 2011). Finally, transgene-driven expressions of EpoR in $\Delta$ Epo $_{\mathrm{E}}$ mice hematopoietic cells and spleen are comparable to endogenous EpoR levels and also $\triangle \mathrm{EpoR}_{\mathrm{E}}$ mice do not show any difference in hematocrit levels (Suzuki et al. 2002, Teng et al. 2011).

Published by Bioscientifica Ltd. 
Leptin receptor is distributed in the arcuate nucleus and other regions of the hypothalamus and in extrahypothalamic autonomic control sites as well as cortex and hippocampus (Caron et al. 2010), indicating that leptin response associated with energy balance involves multiple regions of the brain. EpoR is also expressed in various sites in the brain, such as cortex and hippocampus that are also linked to food intake (Morton et al. 2006, Volkow et al. 2011), raising the possibility that Epo activity in the brain beyond POMC neurons may modulate metabolic activity. Although AgRP/NPY neurons in the arcuate nucleus of the hypothalamus also contribute to leptin regulation of POMC, EpoR expression was not detected in AgRP/NPY neurons (Teng et al. 2011). Moreover, we did not see any difference in AgRP and NPY expression between WT and $\triangle$ EpoRE hypothalamus NPC cultures, and NPY expression was reduced after leptin treatment only. This also suggests that the effect we see in $\triangle \mathrm{EpoR}_{\mathrm{E}}$ mice is specifically due to Epo-mediated regulation of POMC neurons and not due to secondary effects on AgRP and NPY neurons.

Similar to acute leptin administration (Hill et al. 2008), exogenous Epo treatment in WT mice also results in a reduction in food intake and body weight, and an increase in physical activity with activation of POMC neurons (Teng et al. 2011). The uncoupling of food intake and energy expenditure has been observed in POMC neurons, and selective deletion of leptin receptor in POMC neurons fails to affect food intake (Balthasar et al. 2004). It has been argued that neural control over feeding behavior has several layers of redundancy (Schwartz et al. 2003). It should be noted that although the knockout of anorexigenic neuropeptide-expressing POMC gene causes increased food intake (Yaswen et al. 1999), the knockout of orexigenic NPY gene does not affect daily food intake (Erickson et al. 1996). In this regard, we observed that the $\triangle \mathrm{EpoR}_{\mathrm{E}}$ mice that show a $50 \%$ reduction in POMC expression in the hypothalamus develop obesity, with reduced physical activity, but no detectable increase in food intake (Teng et al. 2011).

Endogenous Epo is present in brain and cerebral spinal fluid (Chavez et al. 2006), in addition to the adult kidney, Epo can be produced in an oxygen-dependent manner by astrocytes and neurons (Chavez et al. 2006) and provide a local source for Epo production to stimulate the EpoRexpressing neural cells in the hypothalamus. Interestingly, hypothalamic astrocytes have also been suggested to influence metabolic status and obesity (Fuente-Martin et al. 2012). High fat diet feeding in mice results in inflammatory response and increase in pro-inflammatory markers in astrocytes, together with a decrease in POMC neurons in the arcuate nucleus (Thaler et al. 2012).

Overall, in this study we identified a previously unknown mechanism of EpoR-dependent regulation of POMC expression via STAT3 activation and LepRb signaling in the hypothalamus. We further explored the molecular links underlying the contribution of loss of EpoR in non-hematopoietic tissue to the obese phenotype in $\Delta \mathrm{EpoR}_{\mathrm{E}}$ mice. Our study also identified the importance of endogenous Epo signaling in regulation of energy homeostasis.

Declaration of interest

The authors declare that there is no conflict of interest that could be perceived as prejudicing the impartiality of the research reported.

\section{Funding}

This research was supported by the Intramural Research Program of the National Institute of Diabetes and Digestive and Kidney Diseases, NIH, Bethesda, USA.

\section{Author contribution statement}

$S D$ and $X L$ designed and performed experiments; $S D$ wrote the paper; R T, M A, Z C, H R, contributed by technical assistance, advice, and manuscript revision; C T N developed the concept, supervised the study, and wrote the paper.

\section{References}

Alnaeeli M, Wang L, Piknova B, Rogers H, Li X \& Noguchi CT 2012 Erythropoietin in brain development and beyond. Anatomy Research International 2012 953264. (doi:10.1155/2012/953264)

Anagnostou A, Liu Z, Steiner M, Chin K, Lee ES, Kessimian N \& Noguchi CT 1994 Erythropoietin receptor mRNA expression in human endothelial cells. PNAS 91 3974-3978. (doi:10.1073/pnas.91.9.3974)

Balthasar N, Coppari R, McMinn J, Liu SM, Lee CE, Tang V, Kenny CD, McGovern RA, Chua SC Jr, Elmquist JK et al. 2004 Leptin receptor signaling in POMC neurons is required for normal body weight homeostasis. Neuron 42 983-991. (doi:10.1016/j.neuron.2004.06.004)

Banks AS, Davis SM, Bates SH \& Myers MG Jr 2000 Activation of downstream signals by the long form of the leptin receptor. Journal of Biological Chemistry 275 14563-14572. (doi:10.1074/jbc.275.19.14563)

Bates SH, Stearns WH, Dundon TA, Schubert M, Tso AW, Wang Y, Banks AS, Lavery HJ, Haq AK, Maratos-Flier E et al. 2003 STAT3 signalling is required for leptin regulation of energy balance but not reproduction. Nature 421 856-859. (doi:10.1038/nature01388)

Bouyer K \& Simerly RB 2013 Neonatal leptin exposure specifies innervation of presympathetic hypothalamic neurons and improves the metabolic status of leptin-deficient mice. Journal of Neuroscience 33 840-851. (doi:10.1523/JNEUROSCI.3215-12.2013)

Caron E, Sachot C, Prevot V \& Bouret SG 2010 Distribution of leptinsensitive cells in the postnatal and adult mouse brain. Journal of Comparative Neurology 518 459-476. (doi:10.1002/cne.22219)

Chavez JC, Baranova O, Lin J \& Pichiule P 2006 The transcriptional activator hypoxia inducible factor 2 (HIF-2/EPAS-1) regulates the 
oxygen-dependent expression of erythropoietin in cortical astrocytes. Journal of Neuroscience 26 9471-9481. (doi:10.1523/JNEUROSCI.283806.2006)

Chen ZY, Asavaritikrai P, Prchal JT \& Noguchi CT 2007 Endogenous erythropoietin signaling is required for normal neural progenitor cell proliferation. Journal of Biological Chemistry 282 25875-25883. (doi:10.1074/jbc.M701988200)

Constantinescu SN, Keren T, Socolovsky M, Nam H, Henis YI \& Lodish HF 2001 Ligand-independent oligomerization of cell-surface erythropoietin receptor is mediated by the transmembrane domain. PNAS $\mathbf{9 8}$ 4379-4384. (doi:10.1073/pnas.081069198)

Coppari R, Ichinose M, Lee CE, Pullen AE, Kenny CD, McGovern RA, Tang V, Liu SM, Ludwig T, Chua SC Jr et al. 2005 The hypothalamic arcuate nucleus: a key site for mediating leptin's effects on glucose homeostasis and locomotor activity. Cell Metabolism 1 63-72. (doi:10.1016/j.cmet.2004.12.004)

D'Andrea AD, Rup BJ, Fisher MJ \& Jones S 1993 Anti-erythropoietin receptor (EPO-R) monoclonal antibodies inhibit erythropoietin binding and neutralize bioactivity. Blood 82 46-52.

Diano S, Liu ZW, Jeong JK, Dietrich MO, Ruan HB, Kim E, Suyama S, Kelly K, Gyengesi E, Arbiser JL et al. 2011 Peroxisome proliferationassociated control of reactive oxygen species sets melanocortin tone and feeding in diet-induced obesity. Nature Medicine 17 1121-1127. (doi:10.1038/nm.2421)

Erickson JC, Clegg KE \& Palmiter RD 1996 Sensitivity to leptin and susceptibility to seizures of mice lacking neuropeptide Y. Nature $\mathbf{3 8 1}$ 415-421. (doi:10.1038/381415a0)

Foskett A, Alnaeeli M, Wang L, Teng R \& Noguchi CT 2011 The effects of erythropoietin dose titration during high-fat diet-induced obesity. Journal of Biomedicine \& Biotechnology 2011 373781. (doi:10.1155/2011/ 373781)

Fruhbeck G 2006 Intracellular signalling pathways activated by leptin. Biochemical Journal 393 7-20. (doi:10.1042/BJ20051578)

Fuente-Martin E, Garcia-Caceres C, Granado M, de Ceballos ML, SanchezGarrido MA, Sarman B, Liu ZW, Dietrich MO, Tena-Sempere M, Argente-Arizon P et al. 2012 Leptin regulates glutamate and glucose transporters in hypothalamic astrocytes. Journal of Clinical Investigation 122 3900-3913. (doi:10.1172/JCI64102)

Gao Q, Wolfgang MJ, Neschen S, Morino K, Horvath TL, Shulman GI \& Fu XY 2004 Disruption of neural signal transducer and activator of transcription 3 causes obesity, diabetes, infertility, and thermal dysregulation. PNAS 101 4661-4666. (doi:10.1073/pnas.0303992101)

Harlan SM, Morgan DA, Agassandian K, Guo DF, Cassell MD, Sigmund CD, Mark AL \& Rahmouni K 2011 Ablation of the leptin receptor in the hypothalamic arcuate nucleus abrogates leptin-induced sympathetic activation. Circulation Research 108 808-812. (doi:10.1161/CIRCRESAHA.111.240226)

Hill JW, Williams KW, Ye C, Luo J, Balthasar N, Coppari R, Cowley MA, Cantley LC, Lowell BB \& Elmquist JK 2008 Acute effects of leptin require PI3K signaling in hypothalamic proopiomelanocortin neurons in mice. Journal of Clinical Investigation 118 1796-1805. (doi:10.1172/ JCI32964)

Hilton DJ, Watowich SS, Murray PJ \& Lodish HF 1995 Increased cell surface expression and enhanced folding in the endoplasmic reticulum of a mutant erythropoietin receptor. PNAS 92 190-194. (doi:10.1073/pnas. 92.1.190)

Hojman P, Brolin C, Gissel H, Brandt C, Zerahn B, Pedersen BK \& Gehl J 2009 Erythropoietin over-expression protects against diet-induced obesity in mice through increased fat oxidation in muscles. PLoS ONE 4 e5894. (doi:10.1371/journal.pone.0005894)

Katz O, Stuible M, Golishevski N, Lifshitz L, Tremblay ML, Gassmann M, Mittelman M \& Neumann D 2010 Erythropoietin treatment leads to reduced blood glucose levels and body mass: insights from murine models. Journal of Endocrinology 205 87-95. (doi:10.1677/JOE-09-0425)

Mancour LV, Daghestani HN, Dutta S, Westfield GH, Schilling J, Oleskie AN, Herbstman JF, Chou SZ \& Skiniotis G 2012 Ligand-induced architecture of the leptin receptor signaling complex. Molecular Cell 48 655-661. (doi:10.1016/j.molcel.2012.09.003)

Mengozzi M, Cervellini I, Villa P, Erbayraktar Z, Gokmen N, Yilmaz O, Erbayraktar S, Manohasandra M, Van Hummelen P, Vandenabeele P et al. 2012 Erythropoietin-induced changes in brain gene expression reveal induction of synaptic plasticity genes in experimental stroke. PNAS 109 9617-9622. (doi:10.1073/pnas.1200554109)

Miskowiak K, O'Sullivan U \& Harmer CJ 2007 Erythropoietin enhances hippocampal response during memory retrieval in humans. Journal of Neuroscience 27 2788-2792. (doi:10.1523/JNEUROSCI.5013-06.2007)

Morton GJ, Cummings DE, Baskin DG, Barsh GS \& Schwartz MW 2006 Central nervous system control of food intake and body weight. Nature 443 289-295. (doi:10.1038/nature05026)

Noguchi CT, Wang L, Rogers HM, Teng R \& Jia Y 2008 Survival and proliferative roles of erythropoietin beyond the erythroid lineage. Expert Reviews in Molecular Medicine 10 e36. (doi:10.1017/ S1462399408000860)

Ouyang S \& He F 2003 Phylogeny of a growth hormone-like cytokine superfamily based upon 3D structure. Journal of Molecular Evolution 56 131-136. (doi:10.1007/s00239-002-2385-2)

Schwartz MW, Woods SC, Seeley RJ, Barsh GS, Baskin DG \& Leibel RL 2003 Is the energy homeostasis system inherently biased toward weight gain? Diabetes 52 232-238. (doi:10.2337/diabetes.52.2.232)

Shingo T, Sorokan ST, Shimazaki T \& Weiss S 2001 Erythropoietin regulates the in vitro and in vivo production of neuronal progenitors by mammalian forebrain neural stem cells. Journal of Neuroscience $\mathbf{2 1}$ 9733-9743.

Suzuki N, Ohneda O, Takahashi S, Higuchi M, Mukai HY, Nakahata T, Imagawa S \& Yamamoto M 2002 Erythroid-specific expression of the erythropoietin receptor rescued its null mutant mice from lethality. Blood 100 2279-2288. (doi:10.1182/blood-2002-01-0124)

Teng R, Gavrilova O, Suzuki N, Chanturiya T, Schimel D, Hugendubler L, Mammen S, Yver DR, Cushman SW, Mueller E et al. 2011 Disrupted erythropoietin signalling promotes obesity and alters hypothalamus proopiomelanocortin production. Nature Communications 2520. (doi:10.1038/ncomms1526)

Thaler JP, Yi CX, Schur EA, Guyenet SJ, Hwang BH, Dietrich MO, Zhao X, Sarruf DA, Izgur V, Maravilla KR et al. 2012 Obesity is associated with hypothalamic injury in rodents and humans. Journal of Clinical Investigation 122 153-162. (doi:10.1172/JCI59660)

Tsai PT, Ohab JJ, Kertesz N, Groszer M, Matter C, Gao J, Liu X, Wu H \& Carmichael ST 2006 A critical role of erythropoietin receptor in neurogenesis and post-stroke recovery. Journal of Neuroscience $\mathbf{2 6}$ 1269-1274. (doi:10.1523/JNEUROSCI.4480-05.2006)

Um M, Gross AW \& Lodish HF 2007 A "classical" homodimeric erythropoietin receptor is essential for the antiapoptotic effects of erythropoietin on differentiated neuroblastoma SH-SY5Y and pheochromocytoma PC-12 cells. Cellular Signalling 19 634-645. (doi:10.1016/j.cellsig.2006.08.014)

Volkow ND, Wang GJ \& Baler RD 2011 Reward, dopamine and the control of food intake: implications for obesity. Trends in Cognitive Sciences $\mathbf{1 5}$ 37-46. (doi:10.1016/j.tics.2010.11.001)

Wang L, Zhang ZG, Zhang RL, Gregg SR, Hozeska-Solgot A, LeTourneau Y, Wang Y \& Chopp M 2006 Matrix metalloproteinase 2 (MMP2) and MMP9 secreted by erythropoietin-activated endothelial cells promote neural progenitor cell migration. Journal of Neuroscience 26 5996-6003. (doi:10.1523/JNEUROSCI.5380-05.2006)

Wang L, Chopp M, Gregg SR, Zhang RL, Teng H, Jiang A, Feng Y \& Zhang ZG 2008 Neural progenitor cells treated with EPO induce angiogenesis through the production of VEGF. Journal of Cerebral Blood Flow and Metabolism 28 1361-1368. (doi:10.1038/jcbfm.2008.32)

Wu H, Liu X, Jaenisch R \& Lodish HF 1995 Generation of committed erythroid BFU-E and CFU-E progenitors does not require erythropoietin or the erythropoietin receptor. Cell 83 59-67. (doi:10.1016/00928674(95)90234-1) 
Yaswen L, Diehl N, Brennan MB \& Hochgeschwender U 1999 Obesity in the mouse model of pro-opiomelanocortin deficiency responds to peripheral melanocortin. Nature Medicine 5 1066-1070. (doi:10.1038/12506)

Yu X, Shacka JJ, Eells JB, Suarez-Quian C, Przygodzki RM, Beleslin-Cokic B, Lin CS, Nikodem VM, Hempstead B, Flanders KC et al. 2002 Erythropoietin receptor signalling is required for normal brain development. Development 129 505-516.
Zhang Y, Wang L, Dey S, Alnaeeli M, Suresh S, Rogers H, Teng R \& Noguchi CT 2014 Erythropoietin action in stress response, tissue maintenance and metabolism. International Journal of Molecular Sciences 15 1029610333. (doi:10.3390/ijms150610296)

Zuure WA, Roberts AL, Quennell JH \& Anderson GM 2013 Leptin signaling in GABA neurons, but not glutamate neurons, is required for reproductive function. Journal of Neuroscience 33 17874-17883. (doi:10.1523/JNEUROSCI.2278-13.2013)

Received in final form 10 November 2015

Accepted 12 November 2015

Accepted Preprint published online 12 November 2015
Published by Bioscientifica Ltd. 